\title{
Manifesting the Sacred: John La Farge's The Lampbearer as a Model for Catholic Presence in the World ${ }^{1 *}$ \\ Benjamin LaBadie \\ Boston College School of Theology and Ministry
}

What does it mean for the Church to be in the world? Beauty. Beauty in poetry, literature, theater, symphony, melody, liturgy, stained glass, drawing, painting, and all its myriad forms. For God is uniquely, powerfully, and mysteriously revealed in beauty no matter the belief or background. And so, if the Church wishes to make God's kingdom even more immanent, she must again recover the unified witness of revelation and art. ${ }^{2}$ John La Farge (1835-1910), a Catholic artist "of deep religious feeling," bore witness to this unity of art and revelation in his "lifelong efforts to visualize the sacred." La Farge's works, ranging from paintings to sketches to stained glass, are currently being displayed in the exhibition, John La Farge and the Recovery of the Sacred, at Boston College's McMullen Museum. He was a luminous example of how beauty can reveal God through what Charles Taylor calls "subtler languages." ${ }^{4}$ His works are windows into the mystery of God and life. Given this, I would like to contemplate La Farge's 1881 painting, The Lampbearer (The Parable of the Wise Virgin), in order to show how beautiful art can draw one to God like a glimpse of light draws one to look for the source of light. For the figure in this painting is an illustration of the paradoxical Christian life - awaiting the coming of God's beatific kingdom and yet already making it immanent in love of neighbor. This painting

\footnotetext{
${ }^{1 *}$ I want to thank Jack Pappas and especially Rohan Oberai for their helpful editorial suggestions.

${ }^{2}$ Hans Urs von Balthasar, "Revelation and the Beautiful," in The Word Made Flesh, Vol. I of Explorations in Theology, (San Francisco: Ignatius Press, 1989), 95-126.

3 Jeffery Howe, "Introduction," in John La Farge and the Recovery of the Sacred, ed. Jeffery Howe, (Boston College: McMullen Museum of Art, 2015), 10-11.

${ }^{4}$ Charles Taylor, A Secular Age, (Cambridge, MA: The Belknap Press of Harvard University Press, 2007), 356-361.
} 
reveals what it means to follow Christ, and it compliments the study of theology and the service of ministry. My hope is that this contemplation will illuminate the special capability of art in witnessing to God's love. And perhaps this illumination will encourage the Church to rediscover that special part of her mission in the world: the creation of beauty.

Before moving forward, I want to quickly note the approach I am taking in contemplating La Farge's The Lampbearer. There are multiple helpful ways to engage a work of art. It is analogous to literary criticism. One can take a historical lens to see how the author's life and the historical circumstances influenced the creation of the work. One could even use a feminist, Marxist, or a psychoanalytic approach. These, among others, assist in understanding a created work. Equally as important, but at times neglected, is taking the work as a self-contained entity which reveals its meaning in itself (known as formalist criticism). It is this kind of lens that I will use to contemplate this painting. In brief, I'm only going to consider the painting itself in order to understand what it reveals about God. I leave it for others to approach this painting with the other lenses. The formalist lens seems fitting here since I seek to show how an artistic work can uniquely reveal God. ${ }^{5}$ If successful, my hope is that this contemplation will encourage the Church to consider beauty as essential to her presence in the world.

\section{The Lampbearer: Paradoxical Christian Witness}

As one first looks at the painting, one is struck by the Lampbearer's stature which takes up most of the frame. She appears to be in a plain dwelling. Dressed in full garb and standing with a small lamp, she seems to be waiting and looking for something. The only noticeable aspect of the

\footnotetext{
${ }^{5}$ For those interested in multiple perspectives on La Farge's art, see John La Farge and the Recovery of the Sacred, ed. Jeffery Howe, (Boston College: McMullen Museum of Art, 2015).
} 
background is the open window through which is veiled darkness. It's a hazy and unclear night analogous to God 's invisible presence amid the darkness of a fallen world. The fact that she stands before this window indicates she was gazing out into this mysterious night like a mystic 


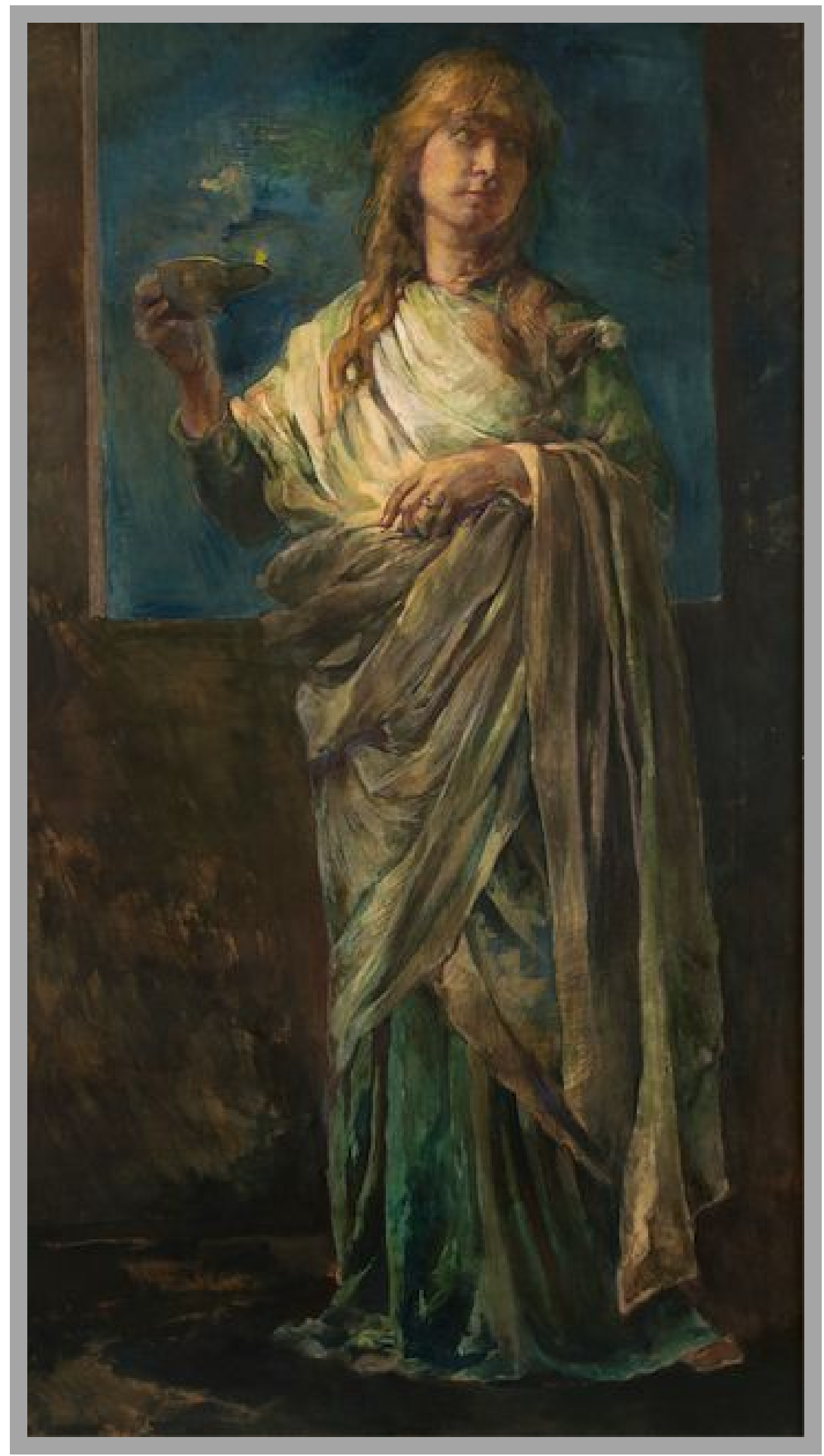

Figure 1. John La Farge (1835-1910), The Lampbearer (Parable of the Wise Virgin), Full-size Cartoon for Gertrude Parker Memorial Window, Parish House, Trinity Church, Boston, 1881. Encaustic on paper on canvas, 55 x 36 in.

Private collection, New York; Courtesy William Vareika Fine Arts, Newport 
seeking to behold the transcendent God. She stands attentively as if waiting for God's unveiling. Although she does not know the day or the hour of God's coming, the Lampbearer faithfully stays alert and prepared for the Lord. The ring on her finger signifies covenantal faithfulness for she perseveres through this period of waiting. And yet, the Lampbearer's faith already begins to reflect God's immanence. In other words, the Lampbearer's faithful watchfulness begins to make God's presence visible.

The lamp's light that helps her stay watchful through the night illuminates God's immanence in her visage. From our view, the right of her face is darkened, and the bags under her eyes stand out showing the effects of finite, tiring existence. Yet the darkness does not overcome her face. The lamp's light illuminating her face signifies the true light who comes into the world and shines in the darkness. ${ }^{6}$ She is not the light, but her face witnesses to the light that does not leave humanity drenched in darkness. Her countenance exhibits Simeon's redeemed exhaustion (which fittingly is the Night Prayer's Gospel Canticle in the Liturgy of the Hours): "Now, Master, you may let your servant go in peace, according to your word, for my eyes have seen your salvation, which you prepared in sight of all the peoples, a light for revelation to the Gentiles, and glory for your people Israel." ${ }^{7}$ This is the Lampbearer's witness to paradoxical Christian life. Although the darkness of the Fall overshadows the world, it cannot overcome the light of God's love. Although God appears absent in the darkness, God is immanent in the Lampbearer's face. She in her finite existence is exhausted yet at rest in God's infinite love.

God's love becomes even more immanent in the Lampbearer's love for her neighbor. How

\footnotetext{
6 John 1:4-9.

${ }^{7}$ Luke 2:29-32.
} 
is this shown since no one else is visible in the painting? Although her presence before the window reflects her search for the transcendent God, it's significant that she is not looking out through it. Instead, she is looking to the side at her present reality. She appears to be gazing at something or someone. Given that she is a Wise Virgin, one is reminded of Matthew 25 in which she awaits the Bridegroom; thus, one can assume she is looking at the Bridegroom arriving. But even so, why is the Bridegroom not visible in the painting? Why is he unseen? Because the unseen Bridegroom reminds us of how God is unseen in our neighbor. Consider how Christ remains unseen yet present in the neighbor who is hungry, thirsty, foreign, naked, ill and imprisoned. ${ }^{8}$ This is the Lampbearer's paradoxical and beautiful manifestation of Divine love. This love is manifest in the Lampbearer who is looking vertically to the transcendent while looking horizontally to the neighbor. In other words, she is at the intersection of a vertical and a horizontal vision. And as we all know, where a vertical beam intersects with a horizontal one is known as a cross. In brief, the Lampbearer demonstrates the Christian's paradoxical cross: we love God by loving our neighbor and love our neighbor by loving God. ${ }^{9}$

John La Farge's The Lampbearer is a beautiful witness to Christ's love. In this work of art, one sees what it means to be the Church. It is one thing to say that the Church lives in the paradox of the transcendent and the immanent where one awaits God's kingdom of love yet

\footnotetext{
${ }^{8}$ Matthew 25:35-36.

${ }^{9}$ See Pope Benedict's encyclical, Deus Caritas Est, where he talks about this paradox of love of neighbor as love of God: "[Love of neighbor] consists in the very fact that, in God and with God, I love even the person whom I do not like or even know. This can only take place on the basis of an intimate encounter with God, an encounter which has become a communion of will, even affecting my feelings. Then I learn to look on this other person not simply with my eyes and my feelings, but from the perspective of Jesus Christ. His friend is my friend." Pope Benedict XVI, Deus Caritas Est (San Francisco: Ignatius, 2006), 45.
} 
already makes it immanent in loving one's neighbor. But it is another thing to behold it visibly and beautifully as we do with La Farge's The Lampbearer. Art provides a vision of God. It certainly does not exhaust God's mystery, but it is a keyhole through which we gaze at God's mysterious love. It is a gentle image of invitation. In this image, we can see the Church's face in the Lampbearer's face - a sacred visage witnessing to God's transcendence and immanence. It is an image of Pope Francis' message of being faithful to God through the marginalized. In Francis' phrasing, to cut oneself off from God makes the Church nothing more than a "well-organized NGO with a bunch of pastoral plans." ${ }^{10}$ And to cut oneself off from one's neighbor reduces one to an "existential schizophrenia" which "often strikes those who, abandoning pastoral service, limit themselves to bureaucratic activity, thereby losing contact with reality and with concrete persons." defective Church. Hers is the visage of the Church immersed in the baptismal tomb who like the Virgin Mary is a locus of the transcendent and the immanent. And like Mary, she can express faithfully to God and neighbor, "Behold the handmaid of the Lord. May it be done to me according to your word." ${ }^{12}$

\section{The Church's Mission in the World: Beauty and Art}

La Farge intuitively knew how powerfully art could manifest the mystery of God and of life. He is a beacon for the Church in showing how art makes God's presence felt. He shows us

10 "Pope Francis: Church a Mother not a NGO," Vatican Radio, June 18, 2014, accessed October 31, 2015. http://www.news.va/en/news/pope-francis-church-a-mother-not-a-ngo.

11 John Allen Jr., "Pope warns Curia against 'spiritual diseases," Crux, December 22, 2014, accessed October 31, 2015, http://www.cruxnow.com/church/2014/12/22/pope-warns-vaticans-upper-echelon-against-spiritu al-diseases/.

${ }^{12}$ Luke 1:38. 
how beauty uniquely communicates the ineffable love of God and is a gentler, "subtler language" that communicates across cultural, religious, political, and socioeconomic background. $^{13}$ And yet, the Church has recently struggled to incorporate beauty and art into her mission. To cite an example, one can look at the decline of the American Catholic literary scene. Sixty years ago it would be impossible to examine the American literary scene without encountering numerous professed Catholics whose faith impacted their work: Flannery O’Connor, Walker Percy, J.F. Powers, Katherine Anne Porter, Walter Miller, Jr., Robert Fitzgerald, Isabella Gardner, Thomas Merton, and the Berrigan Brothers among others. ${ }^{14}$ Today the Catholic literary presence is anemic by comparison. Although there are some authors who admit to being practicing Catholics_-Tobias Wolff, Alice McDermott, Richard Rodriguez-the Church's literary influence has been enervated in a predominately secular literary scene. In light of all this, I invite us to ponder how the Church can revive her presence in the world through beauty, art, and revelation. Does post-modern malaise and spiritual hunger offer a rich opportunity for the Church to witness through beauty? ${ }^{15}$ In what ways can beauty and art be vehicles in which the Church goes out to the marginalized? Through beauty and art, how can the Church minister to what Hans Urs von Balthasar called the "confusion and chaos of the present"? ${ }^{16}$ Christian Wiman, a contemporary poet renowned for his poems on faith, doubt, and

\footnotetext{
${ }^{13}$ Charles Taylor, A Secular Age, (Cambridge, MA: The Belknap Press of Harvard University Press, 2007), 360.

14 Dana Gioia, "The Catholic Writer Today," First Things, December 2013, accessed November 3, 2015, http://www.firstthings.com/article/2013/12/the-catholic-writer-today.

15 Roger Scruton, "Beauty and its corruptions," Catholic Education Resource Center, 2009, accessed November, 3, 2015, http://www.catholiceducation.org/en/culture/art/beauty-and-its-corruptions.html. ${ }^{16}$ von Balthasar, "Revelation and the Beautiful," 126.
} 
mystery, urges us to remember the powerful attraction art has in drawing others to God. As he states, “...within poetry is the same anarchic energy and disabling insight that causes people to seek religion at all. It is the aboriginal energy of existence itself that is missing from most religious services these days. Art has this energy in abundance." ${ }^{17}$

\section{Bibliography}

Allen Jr., John. “Pope warns Curia against ‘spiritual diseases.” Crux, December 22, 2014. Accessed October 31, 2015.

http://www.cruxnow.com/church/2014/12/22/pope-warns-vaticans-upper-echelon-against -spiritual-diseases/.

Domestico, Anthony. "An Interview with Christian Wiman: Being Prepared for Joy." Commonweal, April 16, 2014. Accessed November 3, 2015. https://www.commonwealmagazine.org/interview-christian-wiman.

Gioia, Dana. "The Catholic Writer Today.” First Things, December 2013. Accessed November 3, 2015. http://www.firstthings.com/article/2013/12/the-catholic-writer-today.

Howe, Jeffery. "Introduction." In John La Farge and the Recovery of the Sacred, ed. Jeffery Howe, 9-26. Boston College: McMullen Museum of Art, 2015.

Pope Benedict XVI. Deus Caritas Est. San Francisco: Ignatius, 2006.

Scruton, Roger. "Beauty and its corruptions." Catholic Education Resource Center, 2009. $\begin{array}{lll}\text { Accessed } & \text { November, } & 3 \text {, } \\ \text { http://www.catholiceducation.org/en/culture/art/beauty-and-its-corruptions.html. }\end{array}$

Taylor, Charles. A Secular Age. Cambridge, MA: The Belknap Press of Harvard University Press, 2007).

Vatican Radio. "Pope Francis: Church a Mother not a NGO.” Accessed October 31, 2015. http://www.news.va/en/news/pope-francis-church-a-mother-not-a-ngo.

${ }^{17}$ Anthony Domestico, "An Interview with Christian Wiman: Being Prepared for Joy," Commonweal, April 16, 2014, accessed November 3, 2015, https://www.commonwealmagazine.org/interview-christian-wiman. 
von Balthasar, Hans Urs. "Revelation and the Beautiful." In The Word Made Flesh, Vol. I of Explorations in Theology. (San Francisco: Ignatius Press, 1989), 95-126. 